\title{
4
}

\section{New Challenges and Changing Opportunities: The Differing Responses \\ of Transnational Solidarity Organisations in Germany}

\author{
Ulrike Zschache
}

\section{Introduction}

\section{Transnational Solidarity in Challenging Times}

The late summer of 2015 was the momentum for a new wave of transnational solidarity in German civil society. In view of the exceptionally high inflow of refugees and migrants from Syria, other regions of the Middle and Far East and Africa, established civil society organisations and innumerable new citizen groups, initiatives and volunteers came together to assist the

I am deeply grateful to Christian Lahusen and Maria Kousis for their very helpful comments and suggestions and to Lia Duràn for her support in conducting interviews. The chapter takes up results of the TransSOL research project, which has received funding from the European Union's Horizon 2020 research and innovation programme under grant agreement No. 649435.

\section{U. Zschache $(\bowtie)$}

Department of Social Sciences, University of Siegen, Siegen,

Nordrhein-Westfalen, Germany

e-mail: zschache@sozialwissenschaften.uni-siegen.de

C. Lahusen et al. (eds.), Transnational Solidarity in Times of Crises, Palgrave Studies in European Political Sociology, https://doi.org/10.1007/978-3-030-49659-3_4 
newly arrived asylum seekers. Since August 2015, the German government had temporarily suspended the Dublin Regulations. It opened the borders for people arriving along the Balkan route via Greece and Hungary and abstained from sending asylum seekers back to the countries of their first entry to the European Union (EU). As a result, about 890,000 people applied for asylum in Germany by the end of 2015. Before the backdrop of the difficulties of the German authorities to cope with the situation, a new civic engagement emerged in the name of the so-called new German "welcome culture". Both existing and new civil society groups committed to the provision of direct practical help in response to immediate and urgent needs, providing, for instance, food, shelter, clothing, basic goods, medical assistance, assistance in dealings with the German authorities and orientation and language courses. Transnational solidarity was practised in manifold forms, not only with refugees and asylum seekers in Germany but also with refugees in the European border regions most visibly affected by the new migrant and refugee movements (for instance, in Greece and Italy), along the travel routes (such as the Mediterranean Sea) or in transition countries outside Europe.

On the one hand, these acts of solidarity might be understood as part of a longer tradition of charity and humanitarian help for refugees, especially with regard to the established civil society and welfare organisations and local, often church-related initiatives and groups (Aumüller 2016: 2; Schroeder and Kiepe 2019; Speth and Becker 2016: 13). On the other hand, the perception of the recent challenges as a so-called "refugee crisis" has led to the creation of many new and often informal citizen groups and initiatives, as well as the commitment of large numbers of volunteers, many of whom either became active for the very first time or had previously been engaged in other sectors. Civil commitment for refugees was, thus, no longer confined to faith-related or left anti-racist groups, but it also involved many ordinary citizens from the socio-political centre of society (Karakayali and Kleist 2016). In addition, the newly arising "culture of welcome" created momentum for the self-conception of Germany as an immigration country and strengthened the awareness that integration of migrants needs to be actively promoted (Hamann et al. 2016; Linnert 2018). Against this backdrop, the new engagement for refugees has brought about substantial change and innovation in the area of refugee help, breaking with traditional approaches and principles in the field (Aumüller 2016: 5; Schiffauer 2017: 19). The so-called refugee crisis, 
thus, seems to have opened up a "window of opportunity" (Kingdon 1995) for the mobilisation of new actors, ideas and practices in the area of organised transnational civil solidarity on behalf of refugees and asylum seekers.

According to newer institutionalist and social movement theory, civil society organisations can be regarded as institutional entrepreneurs that try to shape and recalibrate the myths, rules and ideas of fields (DiMaggio 1988; Fligstein 2001; McAdam et al. 1996). Through strategic collective action, institutional entrepreneurs seek to delegitimise prevailing approaches, values and beliefs and infuse and establish new views and concepts (Rao et al. 2000: 240). The success of their efforts depends decisively on their capacity to mobilise resources, recruit and activate group members, gain support and build new coalitions. Moreover, they have to be able to frame issues in such a way that their ideas and aims appear meaningful, acceptable and appealing to broader constituencies (Schneiberg and Lounsbury 2008; McAdam et al. 1996; Fligstein 1997; Rao et al. 2000; Hardy and Maguire 2008; Leca et al. 2009).

Institutional entrepreneurship is facilitated by certain conditions that create momentum for agency and change (Leca et al. 2009: 7). In particular, situations of crisis, conflict and new challenges can provide windows of opportunity for institutional entrepreneurs in order to erode the status quo and introduce change (Fligstein and Mara-Drita 1996; Fligstein and McAdam 2011). Crises can disrupt existing routines and evoke uncertainty about the usual courses of action. Such moments of uncertainty and destabilisation constitute "critical junctures" (Collier and Collier 1991) that foster the emergence of novel actors who might contest the role of established actors in the field, seek to delegitimise existing approaches and introduce their own, potentially innovative ideas and concepts. Moreover, crises and uncertainty may lead to change because the prevailing problem definitions and solution approaches are no longer considered suitable enough to cope with newly arising issues and challenges. These circumstances allow collective actors to reframe the situation, to implement alternative beliefs, values and ideas and to build new alliances (Fligstein 2001; Fligstein and McAdam 2011).

Against this background, I am interested in exploring in more detail the strategies, practices and guiding ideas of transnational solidarity 
organisations (TSOs) (Kousis et al. 2016) that contributed not only to the new wave of transnational solidarity with refugees in Germany but also to the transformation of established principles, values and beliefs in the field. What is more, I wish to expand the focus of this chapter and compare the experiences of German refugee TSOs with experiences of German TSOs in other fields of vulnerability. On the one hand, I will use unemployment TSOs as an example of an area that has been affected by the economic crisis of the past decade. On the other hand, I will look at TSOs in the disability field as an example of an area that has not witnessed the severe impact of recent crises. Both fields will serve as contrasting cases to better understand the specificities of TSOs in the field of refugees, as well as to identify those traits of refugee TSOs that are applicable to other fields of transnational solidarity work. Eventually, the aim is to elucidate how and under what conditions TSOs use crises as windows of opportunity to promote change in their field of action.

\section{Insights into Civil Engagement and Organised Solidarity from Previous Research}

Existing research provides indications that the three fields under review used to be characterised by distinct approaches, which, however, have been subject to various changes in the past decades. Previous civil refugee help used to be characterised by a clear division between charitable service-provision and political (protest) action (Speth and Becker 2016: 39). Until recently, support action for refugees was mainly carried out by the established major charity and welfare associations (Aumüller 2016: 2; Kühne and Rüßler 2000; Schroeder and Kiepe 2019; Speth and Becker 2016: 13). Their refugee help activities focused mainly on the provision of accommodation, care and support services, advice and counselling, but also involved lobbying and advocacy (Rada and Stahlmann 2017: 15-19; Schroeder and Kiepe 2019: 166; Rehklau 2017: 306-312). Since 2004 , integration activities have become a relevant part of their work as a result of the reformed German citizenship and immigration policy and the growing public recognition of Germany as a country of immigration (Rehklau 2017: 306; Schroeder and Kiepe 2019: 178). Next to the 
welfare associations, immediate, practical refugee help was provided by a few local church-related groups and other local initiatives (Speth and Becker 2016: 39). These mainly comprised people already affiliated with welfare and other associations, who were "predominantly anchored firmly within the Christian-denominational milieu" (Kühne and Rüßler 2000: 195) and had a "strong humanitarian conviction" (Aumüller 2016: 2). Political activism and protest action on behalf of refugees were, in contrast, mainly organised by groups and initiatives from the left, anti-racism milieu (Twickel 2016; Karakayali 2018: 15). These politically active groups were mostly, though, not committed to direct forms of practical support (Speth and Becker 2016: 39).

At the time of their emergence in the 1970s and early 1980s (in former West Germany), unemployment initiatives aimed at political awareness raising, mobilisation, claims-making and social and policy change in the face of rising mass unemployment (Baumgarten 2010: 23; Rein 2013: 43-46). Since the end of the 1980s, however, there had been a growing shift in focus from political action towards socio-political serviceprovision and employment projects (Rein 2013: 47-48). In the following, many unemployment initiatives and organisations dedicated themselves primarily to the provision of socio-legal advice, psychosocial counselling, the facilitation of social exchange, support in terms of job seeking and application, and socio-political education (Voigtländer 2015: 28). In comparison, interest representation and other forms of political work and mobilisation have played only a secondary role for many of the unemployment organisations while constituting the major focus of work for a politicised minority of initiatives (Baumgarten 2010: 24; Voigtländer 2015: 28). Yet, to a certain degree, the process of depoliticisation has been encountered by the rise of new politically active (protest) initiatives in the context of the so-called Hartz reforms of 2003-2005 (Baumgarten 2010: 25-26; Lahusen and Baumgarten 2010; Rein 2013: 58-66).

In the field of disability, there are three types of civil society engagement: large charity and welfare organisations that are guided by the traditional ideas of religiously or humanistically motivated charity and care, the political disability movement and self-help groups (Matzat 2010; Tesch-Römer et al. 2017: 655-656). During the 1960s/1970s, disabilityrelated civil engagement became more politicised as concerned groups 
started to raise their voice in public discourse and to make political claims against the widely existing barriers and societal disadvantages (Köbsell 2019: 25-28). In the 1980s, the emerging disability movement started to criticise the charity approach of established disability and welfare organisations and of policy-making in the field, which were guided by the topdown, object-oriented rationale of compassion, neighbourly love and responsibility for disabled people, rather than by the notion of rights or self-determination (Köbsell 2006, 2019). In the following years, the German disability movement developed in two different directions: Some groups started to focus on the establishment of an infrastructure for people with disabilities, like assistive services. Others specialised in political agency, aiming at (self-)representation, self-determination equal participation and anti-discrimination (Köbsell 2006; Maskos and Siebert 2006). Yet, while in their early years, these political groups used to be small, informal and quite confrontational and radical, they are nowadays mostly institutionalised, professionalised and more pragmatic and follow a cooperative approach towards the large, charity-oriented disability associations (Köbsell 2019: 30; Rohrmann 1999).

\section{Data and Methods}

This study is based on qualitative interviews with representatives of 37 German TSOs in the fields of refugees, unemployment and disability that stood out because of their pronounced transnational profile (see Kousis et al. 2016: 32). ${ }^{1}$ In order to retrieve information about the concrete activities and practices of TSOs at ground level, we selected civil society initiatives, groups, organisations, organisational branches or networks that are rather informal and/or non-professional or that only have a few paid staff and operate at the local or regional level. Moreover, we sought to include a balanced mix of TSOs that engage in immediate practical help and political activism in order to account for the various

\footnotetext{
${ }^{1}$ The interviews were carried out between August and November 2016 and were conducted mostly face to face, while a few were done via videoconferencing or over the phone. For more information on sampling, see Introduction to this volume and https://blogs.uni-siegen.de/transsol/ files/2016/12/Integrated-Report-on-Reflective-Forms-of-Transnational-Solidarity.pdf
} 
forms of organised solidarity. Finally, we chose organisations from different regions in Germany in order to reflect the regional variety in the country as much as possible. The whole selection of relevant organisations made use of an IT-assisted, web-based mapping of transnational solidarity organisations in Germany (see Kousis et al. 2018; Kousis et al. 2016; Kousis and Paschou 2016).

Based on transcriptions of all 37 interviews, "summarising content analysis" (Mayring 2004: 268) was applied to those sections of the interview material addressing the dimensions of relevance for the purpose of this chapter. This approach implied an inductive inference of ideas from the transcribed interview material and involved an interpretative, gradual and recursive procedure following the "grounded theory" method (Glaser and Strauss 1967). At the same time, notes were taken about particularly illustrative expressions and typical metaphors.

\section{TSOs' Perception of the National Context with Its Core Challenges and Opportunities}

Crises can provide a particular impetus for change. The question is, therefore, to what extent and in what way recent crises have constituted relevant reference points for the actions of the interviewed TSOs and their activists. In Germany, the "refugee crisis" was of enhanced importance in this respect, but it had different repercussions across the fields and was accompanied by other crisis experiences. In the field of migration and asylum, the so-called refugee crisis led not only to an increase in public and political attention and a massive growth in volunteers but also to a surge in private donations and funding, as well as a growing number of political support schemes for civil solidarity activities in the field. Against this backdrop, a large number of new, often locally embedded and rather informal initiatives, groups and solidarity networks emerged across the whole country, which is well illustrated by the following interview statement:

Last summer, autumn and winter there was this exuberant readiness to help [...], this widespread sentiment of panic that 'we have to do something right now'. [...] Our initiative would not be conceivable without this 
so-called crisis. We emerged out of it. I would never have come up with the idea of committing myself to female refugees before these events. [...] Never in my life had I been engaged in volunteering; and now I am committed to such an intensive volunteering activity. [...] [One has to see] the social engagement that has recently emerged in this city. What kind of people are now volunteering who had never done such thing in the past. [...] What an unpreceded number of people is now actively committed to doing something in order to change and influence society. (Migr2 09/2016)

In addition to the immediate impact of the "refugee crisis", activists highlight that the increase of organised solidarity with refugees also has to be understood as a response to growing populist and right-wing antiimmigration mobilisations with the aim to prevent a further rise in antiimmigration sentiments among parts of society. In particular, it is a reaction to the emergence of xenophobic and Islamophobic movements such as HoGeSa, Pegida and their various local equivalents that accompanied the steady increase in refugee arrivals before 2015. Thus, the perceived need to stand up to racism and to shape a migration-friendly societal environment constituted an important starting point for the mobilisation and collective organisation of civil solidarity with refugees.

The "refugee crisis" was less influential for the unemployment and disability fields. However, it had a certain impact on civic organisations in these two areas, too. Due to the shift in political and public attention and financial resources to the field of refugees, organisations in the fields of unemployment and disability witnessed a certain drop in public awareness for their own concerns and, consequently, a decrease in private donations, funding and volunteers. Apart from the constraining effects on their practical activities, the "refugee crisis" sharpened the awareness of civil society actors that their work is considerably shaped by issueattention cycles and the need to compete over visibility, limited resources and capacities. This is seen as a general problem of civil society organisations, particularly when it comes to ensuring sustainability and long-term support. To some extent, the arrival of refugees also changed the composition of beneficiaries and the challenges TSOs have to cope with because of the overlapping target groups. For instance, new tailor-made forms of support became necessary because of the increased arrival of disabled 
refugees in Germany. In consequence, disability TSOs are now dealing with new issues, such as cooperation with translators and legal experts who are acquainted with asylum law and its implications for rights and entitlements in terms of the provision of disability services and medical aid.

Apart from the effects of the "refugee crisis", representatives of unemployment and disability TSOs point to other contextual conditions that are more specific for their fields. In the unemployment field, it was particularly the impact of the international economic crisis that brought about new challenges to German unemployment organisations. Interestingly, these challenges were quite different from those of their counterparts in many other European countries. Initially, the short stagnation of the German economy between 2008 and 2009 helped to increase public awareness of unemployment during that period. Against the backdrop of a more widespread fear of job loss, people became more sensitised to the structural, societal and economic causes of unemployment. Consequently, there was a growing understanding that unemployment is not an individual fate. Yet, due to the economic recovery and growth in Germany since 2010, unemployment has dropped off the public radar again. What is more, unemployment organisations witness a growing social divide between groups in society that have benefitted considerably from the recent economic growth, on the one hand, and the group of long-term unemployed and precarious workers with low-wage, temporary or service contracts that are left behind, on the other. For them, a major concern is that the issues of unemployment and poverty tend to vanish from political agendas and media coverage, thus contributing to the erosion of solidarity towards these groups in society. As one interviewee puts it:

Since about 2011, we have continuously growing official employment figures. In my view, this leads to a decrease in solidarity because the public is under the impression that the problem has resolved itself. [...] And for those who are still jobless, it must certainly be their own fault. (Unemp1 08/2016) 
In addition, unemployment organisations are concerned that the influx of young and well-educated, skilled workers and professionals from other European countries during the international economic crisis has removed the pressure from the German government to invest in activation and re-integration measures that would help the long-term unemployed and low-skilled temporary workers to (re)gain access to the labour market and/or better working conditions. At the same time, they observe that sanctions and restrictions for Hartz-IV benefit receivers have been continuously tightened and express the fear that this will contribute to weakening the solidarity principle of the social welfare state and to cementing the social divide and isolation of their target groups. ${ }^{2}$ What is more, a decade after the implementation of the Hartz-IV system, unemployment organisations find it increasingly difficult to reach out to and activate their constituencies because of a growing resignation among the long-term unemployed. Against the backdrop of the various direct and indirect effects of the "refugee crisis", the economic crisis in other European countries and the economic and political developments at home, many unemployment TSOs see themselves confronted with the challenge of how to mobilise attention and support in times of a remarkable decrease in public and political awareness for their concerns. This is particularly true for those initiatives and organisations that aim for social and political change. In comparison, for service-oriented organisations, the recent developments created some new opportunities, particularly with regard to new European and domestic funding schemes and activation programmes that are geared to tackle youth unemployment in Europe or the integration of migrants and refugees into the labour market.

For disability organisations, the recent crises had, compared to the other two fields, the least impact according to the interviewed TSOs. Instead, a crucial challenge in this field is the full realisation of equity and inclusion of people with disabilities in society. A major change in their opportunity structures has been the adoption of the UN Convention on

\footnotetext{
${ }^{2}$ In November 2019, the Federal Constitutional Court declared harsh Hartz IV sanctions as unconstitutional (BVerfG 2019). In consequence, Hartz IV benefits cannot be cut down by more than $30 \%$ by sanction measures. In this context, a larger reform of Hartz IV regulations is planned for 2020 .
} 
the Rights of Persons with Disabilities and its ratification by Germany in 2009 and the European Union in 2010:

After the establishment of the UN Convention on the Rights of People with Disabilities conditions have changed. It is no longer a charitable act to do something for the most disadvantaged, but instead, [inclusion] has been enshrined in the political system. (Disab3 10/2016)

On the one hand, the ratification by the national government and the EU helps the field to raise claims and lobby for the comprehensive adoption and implementation of these rights by national and European law. On the other hand, the UN convention requires disability organisations to reflect upon and adjust their own approaches and practices because it implies a fundamental paradigm shift from the idea of charitable, compassion-based and object-oriented help and care to the notion of selfdetermination, equal participation and the exercise of rights.

\section{Activities, Missions and Target Groups in the Fields of Migration, Unemployment and Disability}

\section{Migration}

The various challenges and changing context conditions had significant effects on the practices and activities of TSOs in the three fields. The most fundamental repercussions can be found in the migration field. The sharp rise in the arrival of refugees, which culminated in the so-called refugee crisis, not only fostered the emergence of many new grassroots initiatives and solidarity groups but also decisively changed the nature and range of their activities. Looking at the practices reported by the TSOs under review, it becomes clear that local, small and mainly non-professional, volunteer-based organisations assumed a broad spectrum of direct help, care and assistance activities that formerly used to be provided either by large, professional charity and welfare organisations or by the state itself. 
Due to administrative overload and policy restrictions, civil society organisations and private initiatives stepped in to fill the gap-for instance, when it comes to providing food, clothing and items for personal hygiene in reception facilities, arranging medical treatment, offering education and integration services or organising civic sea rescue in international waters between Africa and Europe. One example among other similar statements underscores this point:

In principle, we assume a task that is originally the job of the state. [...] What we aim for is to make ourselves redundant. What we really want is that state authorities will finally assume this genuine state responsibility. This is their job and actually there are clear rules for this. (Migr7 17/2016)

And another interviewee explains:

[The Mediterranean Sea] is a new place or space for networking. [...] Where the military of different national entities operates. This is a space where suddenly civil society is present because [...] otherwise people would die. [...] this space is being civilised. [...] It is simply a new place that civil society and civil society groups are about to appropriate. (Migr3 9/2016)

In more general terms, practical help and support action on behalf of refugees includes, for instance, the provision of help in initial reception facilities; the organisation of donation activities for basic needs supply; German language tutorials; arrangement of free and anonymous medical assistance for undocumented migrants; socialising, cultural, educational and sports activities; information about the German educational and employment systems; preparation for the job market; mediation to find private accommodation and flat-shares; preparation for asylum procedures; and arrangement of legal assistance and advice.

Secondly, it is striking that the work of all interviewed TSOs is more or less openly or subtly embedded within a political mission. Some of the organisations aim explicitly for policy change and have a clear focus on awareness raising, campaigning, lobbying and political activism, including participation in demonstrations, political protest and strike support action. Furthermore, some of these groups advocate for their 
beneficiaries' rights, for instance, through arranging legal support and assisting lawsuits in exemplary cases. Many of the interviewed TSOs are committed to both practical and political activities to a similar extent. Often, pragmatic forms of solidarity are explicitly linked to political aims and awareness raising and, depending on the organisational capacities and degree of politicisation, also to political claims-making and protest action:

Of course, we as volunteers realise that we take over tasks from the state [...]. But currently there are very many protest movements and initiatives in Germany and events [...] where civil society addresses politicians with concrete demands. [...] It is not the case that the volunteering field would approve a leaning back of the state. No! Our activism goes along with many, many demands. [...] All initiatives that I know work actively, but at the same time they make [political] demands. (Migr1 09/2016)

Some of us offered to accompany [refugees] to the local authorities. Others have organised and accompanied child-care or mother-child-areas. And we were cooperating with emergency shelters. [...] And what is of course always very important to us is to draw attention to existing grievances and to have a political voice. (Migr5 10/2016)

In comparison, other TSOs are primarily dedicated to providing immediate practical support to refugees and caring for urgent needs. They are not directly or openly politically active due to limited capacities or because they aim to appear neutral in order to attract a broad spectrum of volunteers and supporters. However, even those organisations focusing on practical activities emphasise that they understand their work as a political statement in itself to demonstrate solidarity with refugees and to send a signal against restrictive European and national asylum policies and/or populist, right-wing and in part xenophobic developments in society:

That we have a political agenda is self-evident for everybody who is a little interested in our work. But the focus should be on helping. Awareness raising. [...] But we actually don't do that on a political level. [...] I want that 
people help because they want to help. [...] And not because of a [certain] agenda. [...] It is better to do that with a soft method [...]. (Migr2 09/2019)

As regards the question of political influence, it is for sure highly frustrating to know that we are providing humanitarian help, but can actually barely shape anything. [...] As long as we spend all our resources, financially and also in terms of manpower, on safeguarding [those in need] in order to achieve our primary objective, there is little space for advocacy and political lobbying. [...] The action itself is a political statement; and the question is how to frame this political statement officially. [...] We believe there must also be organisations that do not do that so offensively and are therefore more compatible to win even more people as supporters, [...] seeking broad societal consensus. (Migr3 09/2016)

At a closer look, it emerges that particularly the practical direct help activities and services are characterised by a great variety of new approaches, experimentation and innovation. This applies to both older and newly established TSOs, as both of them have assumed completely new tasks in the context of the "refugee crisis" and have had to respond to new challenges and demands. Not surprisingly, the commitment to try out novel approaches and activities is particularly pronounced in the young TSOs, working with new activists and volunteers from various societal backgrounds. Many of the interviewees emphasise that their offers are not predefined or ready-made. Instead, organisations follow a bottom-up strategy and take the actual needs and ideas but also reservations, uncertainties or timidities of beneficiaries as a starting point and develop their support activities along these new and often changing inputs in very flexible and dynamic ways. For instance, one project developed a mentoring programme for minor refugees that helps them participate in cultural, sports and other leisure activities:

When we started [...] with summer camps [...], we discovered a gap, or better, a need that these young people have. [...] I see a lot of innovation in our concept with regard to the fact that we always seek to adapt ourselves to the requirements of the young people. Thus, the projects that we initiate are almost always new. (Migr1 09/2016) 
Moreover, some projects have developed new ways of offering tailormade programmes for female refugees, including, for instance, German lessons, mentoring and women-specific information and advice. Most importantly, all of these activities are carried out by female volunteers and are exclusively offered to women. The various activities take place within the reception facilities. This approach is motivated by the observation that female refugees take part neither in activities outside the reception centres nor in mixed-group activities:

Many women [...] did not use the German language offers. [...] They did not have the courage. Here we simply saw a need and have created offers [...] where women teach women in order to reduce their inhibitions. [...] And we were faced with the challenge of mobility, which these women simply do not have. [...] This means we are in the initial reception facilities. [...] We want to provide the women with a protected space [...] where women can be among women. (Migr2 09/2016)

\section{Unemployment}

In the unemployment field, the interviewed organisations deal with a variety of activities concerning unemployment, qualifications and (re-) employment, protection of workers rights and the improvement of working conditions, social exclusion and poverty. Some of them are merely service-oriented and barely politicised. The most service-oriented TSOs are typically those that offer qualification and training activities geared to improving employability and job market chances of their target groups, or provide supported employment opportunities. This type of TSO is often involved in public funding programmes and takes a neutral, pragmatic stance towards social and activation policies. For several of these TSOs, activities are embedded within European funding schemes such as the ESF, Erasmus Plus, the European Voluntary Service as part of Youth in Action or regional programmes aimed at the integration of migrants and refugees. Taking a transnational approach towards target groups, transnational cooperation with organisations from other European countries and offering activities for migrants and refugees at 
home are practices that are certainly facilitated by the related possibilities to get access to additional funding opportunities. The activities and services that are part of these programmes are explicitly geared to tackle current challenges. For instance, they are directed at preventing or mitigating youth unemployment in Europe or promote the preparation and integration of refugees and migrants into the domestic employment market.

In contrast to the few purely service-oriented TSOs, most of our interviewed unemployment organisations engage in various political forms of solidarity action. Among the politicised TSOs, there are some with a predominantly political agenda, engaging mainly in awareness raising, demonstrations, political protest and strike support action. The majority, though, combines political activism, campaigning and lobbying with practical support services. The practical dimension of their work involves, for instance, social and legal advice, counselling, mentoring, social groceries and kitchens, clothing and item provision and collecting donations and social, cultural and educational activities. Overall, the activities of most of the interviewed TSOs point to a remarkable (re-)politicisation of solidarity action on behalf of the unemployed. Since the introduction of the Hartz-IV scheme more than a decade ago, unemployment organisations have observed how the individualisation of the issue of unemployment led to increased feelings of powerlessness and helplessness and a lack of perspective and, in consequence, to resignation, a withdrawal into the private sphere and declining political resistance of the affected people. In the context of the recent European economic crisis, their isolation and marginalisation have even been aggravated. In times of a prospering German economy that benefitted from national recovery programmes and severe economic difficulties in other European countries, it is a widely shared experience among TSOs that (long-term) unemployment and precarity have become more and more stigmatised as a matter of individual fault and fate, leading to a further decrease in societal solidarity, while the regulations of the Hartz-IV scheme have been further tightened. Against this backdrop, many of the TSOs' political activities aim to overcome the widespread resignation and marginalisation, enforce the rights of the unemployed more effectively, achieve a renewed politicisation and mobilisation of unemployed persons and reinvigorate their 
self-confidence. However, in so doing, they are also required to apply new strategies, as the context conditions for successful political action have become more difficult due to decreasing societal awareness on the issue of (long-term) unemployment in Germany. In response, politically oriented TSOs seek to achieve their aims more effectively by bridging the divide between different social groups and uniting them in larger solidarity communities that act jointly for a common cause. They aim to overcome the representation of particular interests in competition with other social groups and are opening up their well-defined target groups to a larger circle of people enduring economic and social pressure:

For me, a crucial approach is to identify the common interests of different groups. If we walked around in a shirt claiming 'more money for long-term unemployed' [...] this would poorly meet with approval. Highlighting interrelations helps much more. [...] To simply ask: Who is benefitting from this policy? Who is losing out because of it? And then it would be helpful if the losers unite and try to enforce their interests in solidarity. [...] We already had such a cooperation model where we aimed to make such a link: [...] Fair prices, fair wages and fair social benefits. (Unemp1 08/2016)

The promotion of a solidarisation process does not only occur across different societal groups, but also occurs across countries. In view of overlapping and interconnected issues, unemployment organisations engage in new forms of collaboration and joint campaigning with different groups, such as farmers, ecologists, precarious workers, the working poor, refugees, migrant workers or workers in crisis-ridden countries such as Greece or Italy. Solidarisation involves, for instance, social benefits at subsistence level for all persons in Germany, be they unemployed natives, EU migrant workers or asylum seekers. Another aspect is the interrelated problem of low social benefits, on the one hand, and the payment of dumping prices for agricultural products on the other. In this regard, another interviewee explains:

In the discussion about the standard rate of welfare benefits, it was a completely new approach to say that these rates are also bad for farmers in 
Germany and outside Europe. [...] To make seemingly impenetrable interrelations visible. That is important. (Unemp2 09/2016)

\section{Disabilities}

In comparison to the more politicised refugee and unemployment TSOs, the disability organisations under review tend to be largely help- and service-oriented. The activities of the analysed TSOs are typically directed at providing support and assistance in many areas of life, such as health care, housing or education, and aim to improve the well-being of people with disabilities, including the medical, socio-economic and sociocultural living conditions. For instance, TSOs furnish information and expertise, support medical research, engage in preventive measures and rehabilitation, and offer services and facilities ensuring appropriate support and aids (for instance, workshops, housing and outpatient services), cultural and sports activities, qualifications, advice, counselling and legal support, organising exchange in self-help groups and contributing to development aid. To a certain extent, most of the TSOs of our study also engage in awareness raising, networking, interest representation, advocacy and lobbying. Differences in the types of activities between local or regional branches of welfare organisations and self-help organisations are mostly gradual rather than categorical, depending on the capacities and focus of each organisation.

Both service-oriented and policy-oriented activities are shaped by the aims and ideas that have become enshrined in the UN Convention on the Rights of Persons with Disabilities. On the one hand, service-oriented activities are increasingly designed to enable persons with disabilities to lead more self-determined and independent lives, foster equal opportunities, fight discrimination and promote their active participation and inclusion in all areas of life. On the other hand, political activities seek to promote the full and de facto implementation and enforcement of these rights in legal regulations, policy-making and administrative practice. As a particularity of the selected TSOs under review, the efforts geared to promote inclusion and equal opportunities do not only target disabled 
people in Germany but often also target beneficiaries and addressees in other countries inside and outside Europe.

Organisations of our study address, for example, inclusive schooling in developing countries or mobility and sports as important dimensions of inclusion and participation in society. Small independent non-profit associations are the forerunners when it comes to trying out innovative and alternative concepts, for instance, cultural activities and arts projects as new forms and means of activation and inclusion. In these instances, innovation is not triggered by recent crises. Instead, it is promoted by particular activists with a strong vision of an inclusive society. Having a background in the cultural sector, these institutional entrepreneurs consider "culture always [as] a pioneer of things that need to change within society as a whole" (Disab2, 10/2016). What they find particularly innovative about their concept is their broad understanding of inclusion and the diversity-oriented character of their companies in which artists with and without disabilities, with multiple talents and skills and from various backgrounds (e.g., from different religions, from different countries, from different sexual orientations, elderly people, refugees and homeless people) work closely together on diverse topics and in multifaceted forms. As one interviewee points out:

A main objective for us is the extended definition of inclusion [...] Of course, we see ourselves as innovative in what we do. What makes this special is that it distinguishes us from [...] a theatre for disabled people [...]. We don't do that. Disabilities are one part of the extended concept of inclusion. (Disab4 10/2016)

What makes their work distinct is the extended conception of inclusion and the objective to contribute to a diverse society in which disabled people are just one among many social groups within a multifaceted inclusive community. 


\section{Solidarity across Borders}

The changed contextual conditions within which TSOs in the fields of refugees, unemployment and disabilities find themselves do not only influence their activities and strategies at home, including their support of beneficiaries with migrant or refugee backgrounds. They also shape how TSOs develop and make use of transnational solidarity relations.

Particularly in the fields of unemployment and refugees, building and strengthening transnational cooperation and solidarity action are a direct response to the impact of the multiple crises of the past decade. Several of the interviewed TSOs established partnerships with organisations from other European countries, on top of their domestic core activities, in order to identify common problems, to compare and better reflect on strategies and solution concepts and to gain a louder voice in Europe. Especially for highly politicised unemployment TSOs, transnational political cooperation, dialogue and mutual solidarity support are used as important means of transnational awareness raising about the multifaceted repercussions of the economic crisis and the situation of unemployment in Europe. Attention is shifted, for instance, to the impact of the economic crisis and austerity programmes on workers' and union rights, precarious temporary work and service contracts or exploitative working conditions in other countries:

One point [is] to collect knowledge from the various countries bottom-up. And then to identify commonalities. And to prevent the rise of a misleading picture, for instance, about the unemployed in Germany and [...] in Italy. Hence, to build the foundations for cooperation by learning about similarities and also the particularities of different countries. (Unemp6 10/2016)

Moreover, transnational partnerships have the purpose to engage in joint political events and campaigns and to support strike action in partner countries:

We make use of all occasions to come together with union people from other countries, to exchange information and to provide mutual help. [...] 
We travel there to show our solidarity with their resistance [...]. Events, common dialogue and political campaigns. [...] We have participated in their demonstrations [as] a sign that there is support for their fight from Germany, too. (Unemp7 10/2016)

These kinds of partnerships typically involve reciprocal relationships of mutual solidarity, support and reinforcement among the organisations. In addition, the various forms of transnational alliance building and awareness raising are a means of mobilising solidarity of the German public with the unemployed, precarious workers or poor people in other countries, but also to re-shift attention to the issue of (long-term) unemployment and poverty in the German debate in response to the decline in public awareness of these issues in this country.

In the migration sector, some politically oriented activists engage in knowledge exchange, investigation and observation and information about the European border regions, namely in the geographical "hot spots" (Migr11 10/2016) along the migration routes or at the Mediterranean Sea. For this purpose, they built close partnerships with local and international organisations in Italy, Greece, Serbia and Turkey. Due to their particular awareness of international developments, they started to react to the new challenges in the migration field more than a decade ago, hence a long time before the topic landed at the top of the German public agenda.

Next to these political forms of transnational solidarity, the recent crises have also triggered the development of practical forms of transnational solidarity. In the unemployment field, some politically oriented TSOs, in particular, started to provide direct help for people from countries suffering from the economic crisis and built, for instance, partnerships with Greek volunteer organisations and social clinics in order to mitigate the impact of the economic crisis and austerity policy (for instance, by collecting and providing donations). In comparison, in the refugee sector, TSOs work to capacity simply by providing support for refugees at home. However, some of the interviewed TSOs made it their mission to respond to the challenges of the recent migration and refugee movements outside Germany. In reaction to the perceived humanitarian crisis, these TSOs emerged explicitly to provide help to refugees in need 
along their migration routes in the European border regions or in transition countries outside of Europe, or to organise civic sea rescue in international waters between Africa and Europe.

In contrast to the multiple forms of transnational cooperation and engagement that have emerged in reaction to recent crises and challenges, there are other examples of transnational solidarity that have a longer tradition and are less influenced by specific issue-attention cycles. In these cases, transnational solidarity takes the form of help projects for groups and people in need in less advantaged parts of the world (such as in Eastern or South-eastern Europe, the Middle East, Africa and Latin America), either as a supplementary activity to the organisations' domestic core activities or as their main activity. In the framework of our study, this form of transnational action is provided by several disability organisations and by a regional branch of a welfare organisation dealing with unemployment and poverty. It involves, for instance, financial support (like fundraising and the provision of donations, e.g., for medicine and medical devices, poor relief and soup kitchens), experience and knowledge exchange or the support of local actors (like helping the locals to build up new structures, such as self-help workshops, infrastructure for education/training, supported employment opportunities and local selfhelp groups). In addition to concrete support, it is striking that these transnational projects are often committed to promoting empowerment, emancipation and capacity building of local groups. In the disability field, this means, for instance, helping local actors advocate and enforce the rights of persons with disabilities and improving social inclusion and equal opportunities for the participation of disabled people in these less advantaged countries.

What the various forms of transnational cooperation and solidarity across the three fields have in common is that they are highly dependent on time and human resources. Normally, the organisations already have to cope with a very high workload with regard to their core activities. The lack of time and capacities are the main reasons why transnational solidarity work is generally perceived as important, but put into practice only to a limited extent. This is particularly true for organisations that are small and/or highly reliant on volunteers. Generally, transnational engagement relies strongly on personal commitment, enthusiasm, 
personal connections and perseverance of a well-defined circle of organisational members or individuals, and it is often poorly institutionalised within the organisations. In comparison, intensive transnational solidarity activities with partners from abroad can only be ensured by organisations that pursue international solidarity work as their main purpose and that are equipped with the necessary staff and resources.

\section{Innovation in Solidarity: Missions and Conceptions}

It is striking that many of the interviewed TSOs across the three fields aim to establish a new understanding of what (transnational) solidarity should mean. Interestingly, despite the very different context conditions and challenges in the three fields, their new approaches point in a similar direction. Across all three fields, TSO representatives repeatedly emphasise explicitly that they do not want to help in a charitable, compassionbased sense or treat their target groups as passive aid recipients. They often reject "asymmetric" and "paternalistic" top-down relations and the treatment of their beneficiaries as "mere objects" of ready-made forms of help:

Often the term 'helper' is used. But we reject this. We do not want to see ourselves as 'helpers'. [...] This project stood out because of the attitude to meet at eye-level [...]. We are not the wealthy white 'helpers' from Berlin. (Migr4 10/2016)

Many TSOs aim to interact with their target groups as "equals at eye level" and seek to integrate them as much as possible into the organisational activities in order to overcome the divide between those who provide and those who receive support. An interviewee from the migration sector explains, for example:

It is our aim to work with refugees at eye level in order to give them access to services they are entitled to and in order to support them in their own political struggles. What is important, not as a charity-approach 'we help 
them', but as real support at eye level. [...] Half of our active members are refugees themselves. (Migr8 10/2016)

This new approach also involves transferring responsibilities to and fostering capacity building of local self-help organisations in target countries. In this regard, an organisational representative of the disability sector highlights:

We understand solidarity in such a way that we do not [...] look down from large to small, or from North to South, [...] who is the recipient, who needs to say 'thank you', who says 'you are welcome'. Instead, the services that we induce are implemented by local partner organisations as a realisation of existing human rights. [...] We do not see this from a charity perspective. (Disab3 10/2016)

The TSOs' activities across all three fields are geared to empowering and activating their beneficiaries in order to enable self-initiative, self-reliance, self-organisation and self-representation. This approach is opposed to one-sided top-down directed help, placing the recipients of help in a dependency relationship. While these ideas are not completely new in the unemployment and disability fields, they are a clear novelty in the refugee sector. While in the past, refugee help was considered mainly an act of humanitarian help during a specific crisis (Aumüller 2016; Kühne and Rüßler 2000), the TSOs under review perceive these new objectives as more appropriate and also important for a successful integration of refugees with a long-term perspective of staying in the country. As one activist of an initiative for female refugees highlights:

We want to make these women visible, [...] give these women a voice, [...] contribute to their emancipation, $[\ldots]$ support them so that they can live here independently. [...] We should not take the entire burden from these people. They are grown-up adults. [...] We should let them make things by themselves. Self-reliance! (Migr2 09/2016)

The long-term objective should be that refugees build up their own organisational structures. [...] This German perspective always has a whiff of paternalism. [...] Someone is giving and the other one is taking something. 
This implies an infant's perspective, a victim's perspective. This is a difficult approach, which I do not want. I would like them to develop their own plans, to propose their own ideas, which we can then try to realise jointly [...]. To enable them to establish their own associations or initiatives. [...] People who will presumably stay here should find their way into these structures. [...] In consequence, they become participants themselves, are self-responsible. This leads much more to the strengthening of their self-esteem, that they can actually be equal actors. [...] We have to work towards this in the next couple of years. [...] Otherwise, we would have to keep up the current helper structures over the next 15 years, which is unrealistic. (Migr12 11/2016)

In the field of unemployment, the notion of empowerment is enshrined in a revised self-conception that rejects the image of the unemployed as passive social welfare aid recipients. Instead, it promotes an active, powerful, subject-oriented self-image. In particular, the more critical and politicised unemployment TSOs seek to reinvigorate the self-confidence, the feeling of dignity and self-determination of the (long-term) unemployed and to change the role of unemployed people as mere aid recipients of one-sided charitable acts of help into the role of self-responsible, active agents. Here, the aim is also to get the long-term unemployed and working poor people out of their isolation, to raise their awareness about their rights and to encourage their (re-)politicisation:

Many people have been activated to state 'I will no longer give up my rights'. [...] What was innovative for us was that we did not say 'The situation of the unemployed can only be changed in Berlin' [...]. Nonsense! People can themselves become politically active subjects. By identifying weak points where it is possible to break out of this invisibility and, by creating bonds of solidarity, to make the problem again a publically discussed problem. This is an alternative approach, namely the complete opposite of the idea 'the poor cannot do anything'. [...] Of course the unemployed can organise themselves and create political pressure through targeted action! (Unemp2 09/2016) 
For some representatives from the disability field, the notion of empowerment is even not far-reaching enough. For them, having equal opportunities is a right that does not require to be granted by a third party:

'Solidarity' is perhaps a term that is already a bit worn-out. [...] 'Empowerment' actually also suggests that somebody empowers someone else to do something. Actually, that implies again a hierarchy or a difference. 'Equality', 'equity', [...] 'inclusion' [I would say]. [...] 'At eye-level' this may sometimes also appear a bit contemptuous, [...] perhaps one of the two of us has condescended to do something. (Disab6 10/2016)

\section{Discussion}

Overall, such reflections about the understanding of solidarity and the adequate approach towards target groups have been mainly addressed by the more politicised TSOs but hardly at all by the strongly serviceoriented TSOs. In the field of refugees, the new approach can be partly explained by the engagement of new actors and initiatives. On the one hand, several of our interviewees were already active in left-wing political or anti-racism groups in the past. Their previous experiences and their knowledge about political concepts, such as "racisms" (Migr3 09/2016), "critical whiteness" and "asymmetric power relations" (Migr4 10/2016), shape the way they conceptualise concrete solidarity action. And many of these actors want to distinguish themselves from how refugee help was carried out in previous times, most often by charity or church-related organisations. On the other hand, there are TSO activists with no previous experience in voluntary or political work. To some extent, these new activists have become more critical due to their direct experiences during their engagement with the impact of political and administrative practices on refugees and have thus assumed a more political approach over time. In addition to ideological motivations, they prefer a bottom-up, inclusive approach partly because of their lack of expertise but also because of the novelty of the new challenges and the uncertainty about adequate solution approaches. In addition, the only recently growing self-perception of Germany as an immigration country and the new 
"welcome culture" provide important foundations for this ideational change. While in the past, migrants and refugees were expected to leave the country after a certain time, a new awareness that these people will stay longer and, hence, need to be integrated into society and enabled to lead an independent life is spreading and affecting the work of TSOs.

In comparison, in the field of unemployment, the revised understanding is not so much due to the intervention of new actors in the field, but rather due to the enhanced re-politicisation of many unemployment TSOs and the awareness of the urgency of political re-mobilisation and change after a decade during which the problems of (long-term) unemployment and precarity have become individualised and largely invisible. And it is also in response to the continuous tightening of unemployment policies, sanctions and controls-largely outside public attention. This enhanced politicisation is particularly true for those TSOs that have already had a political mission or advocatory approach, while the serviceoriented TSOs mainly address the practical dimensions of their work.

In contrast to the other two fields, the revised understanding of disability TSOs about appropriate solidarity conceptions and approaches towards target groups is not so closely linked to recent challenges. In very general terms, the ideas expressed are grounded within a larger discourse that partly dates back at least to the 1960s and 1970s. However, with the ratification of the UN Convention on the Rights of Persons with Disabilities by Germany in 2009, the notions of inclusion and equal opportunities as human rights have become particularly relevant for the work of TSOs in the sector while the ratified UN Convention itself provides an influential reference point for their claims-making.

\section{Conclusions}

Organised transnational solidarity with vulnerable groups is practised against the backdrop of country- and field-specific circumstances. Newly arising challenges, crises and uncertainty may, however, disrupt the normal flow of events and help institutional entrepreneurs transform existing rules and routines and introduce innovation. In Germany, the developments that accompanied the arrival of a high number of refugees in 2015 
and 2016 are a very illustrative example of how a perceived crisis has been used to promote change. Our own observations are in line with other studies that have been published recently in reaction to the "refugee crisis". Publications concerned with the collective level of organised refugee help in Germany widely agree that the recent developments not only have boosted the quantity of civil society initiatives, groups and organisations but have substantially changed the composition of collective actors in the field, the range and types of activities, objectives and approaches and the division of tasks (Aumüller et al. 2015; Aumüller 2016; Speth and Becker 2016). Several recent studies also confirm the new combination of practical, care- and needs-oriented support action and political approaches and actions (Hamann et al. 2016; Karakayali and Kleist 2016; Speth and Becker 2016), as well as the relevance of political motivations on direct refugee help, like preventing a hostile opinion climate and right-wing mobilisation or changing policies (Daphi 2016; Hamann et al. 2016: 14; Misbach 2015; Schiffauer 2017; Schmid 2019: 124; Speth and Becker 2016: 8; 37-38; Sutter 2017). In line with our own findings, other scholars shift attention to the fact that political objectives are not always openly propagated, but they sometimes guide the organisational work in a rather subliminal way (Karakayali 2017). ${ }^{3}$

Overall, the developments and experiences of TSOs in the field of refugees are in large parts rather specific. Both the challenges and opportunity structures and the responses differ remarkably from those of TSOs in the unemployment and disability field. If there is a direct parallel, then it exists due to the fact that unemployment TSOs have also been affected by a recent crisis, namely the European economic crisis. However, this crisis created completely different circumstances for unemployment TSOs. Instead of leading to an enhanced public and political issue awareness and the opportunity to establish new initiatives, enable the rise of new actors

\footnotetext{
${ }^{3}$ In contrast, Steinhilper and Fleischmann (2016) criticise the rather unpolitical and primarily needs-oriented, humanitarian character of the recent refugee help engagement. However, their assessment is based on a very strict definition of political action. Moreover, their study targets volunteers, while our own study has been conducted with founders, leaders or responsible core members of TSOs. In fact, the two observations are not necessarily contradictory. While key TSO representatives mostly pursue a political mission or perceive their organisations' work itself as a political statement, they are aware of the diverse motivations and attitudes of volunteers and therefore partly abstain from making official political statements.
} 
and mobilise new resources, volunteers and supporters, the European economic crisis went along with a decreasing visibility and attention for the societal and political determinants of long-term unemployment and precarity among Germans. On top, public and political attention was additionally shifted away from these problems towards the refugee issue. This situation provided little incentive and no additional resources that would have triggered the emergence of new institutional entrepreneurs or the attraction of new members and volunteers. Change occurred, nevertheless, and it was promoted by already existing, mostly politically oriented TSOs. Most strikingly, existing TSOs used the unfavourable context conditions as an inducement to find new ways of mobilising solidarity and support for unemployed people. Of key importance for this change is the fact that unemployment TSOs adapted their strategies by reframing grievances and solution approaches, redefining constituencies and building new alliances. With their new approaches, TSOs aimed to reach beyond the typical particularistic strategies and started to identify interlinkages and overlapping issues of broader social concern, to align their problem definitions and action strategies towards new constituencies and to coalesce with various other groups in German society and beyond in order to struggle in solidarity for a common overriding cause. Hence, their "frame alignment" (Snow et al. 1986) and strategic alliance-building activities had both a cross-sectoral, intersectional dimension (for instance, by a solidarisation with precarious workers, farmers, refugees, migrant workers, other poor people, etc.) and a transnational dimension (by collaborating with other European TSOs and international TSOs, such as those from Greece). ${ }^{4}$ This finding resonates well with recent scholarship on transnational solidarity movements highlighting that solidarities are actively constructed as part of struggles over power relations (Bandy and Smith 2005; Featherstone 2012; Waterman 2001). According to this literature, political activists lead strategic efforts to bridge differences and align the definition of grievances, group identity and appropriate action. Solidarity and collective identity are thus created through the

\footnotetext{
${ }^{4}$ Such cross-sectoral and transnational strategic coalition-building has, to some extent, already been tested during the 1980s and early 1990s (Rein 2013: 47-49). However, this strategy has been replaced by other priorities during the 1990s.
} 
construction of new links between different activists and social groups, as well as between different places and parts of the world (ibid.). Hence, this strand of research underlines that TSOs must "advance strategic frames and foster group identities that motivate members to engage in collective action. [...] Such identities are negotiated and re-negotiated by activists themselves, as group members work in an ongoing way to define a collective 'we' and its relation to opponents" (Smith 2002: 506).

Compared to the other two fields, TSOs in the disability field have not been affected by concrete crises in recent years. Their opportunity structures are shaped by the international discourse about the enforcement of human rights and, in particular, the ratification of the UN Convention on the Rights of Persons with Disabilities by Germany in 2009 and the EU in 2010. Against this backdrop, existing TSOs have developed services and activities that help disabled people in Germany, in other European countries and in countries of the "Global South" to lead a life according to the principles of inclusion, equality and equity. Those with a more advocatory or political approach take action in order to achieve a full implementation of the enshrined rights of equal participation and anti-discrimination in political regulation and administrative practice, for instance, by means of awareness raising, lobbying, campaigning, protest or legal action.

Despite the very different contextual conditions and ways TSOs responded to challenges and opportunities in their environment, there are some similarities across the different fields. To some extent, these similar features also resemble developments in transnational solidarity organisations and movements on a global scale. First, our study suggests a trend of increased (re-)politicisations, which has already been observed by international social movement scholars with regard to more recent transnational solidarity organisations and movements (Baglioni 2001; Passy 2001; Zamponi 2017; Zamponi and Bosi 2018). In the context of our own study, this (re-)politicisation is particularly true for TSOs in the area of refugees and unemployment. Most strikingly, German TSOs addressing refugees have largely bridged the division of tasks between serviceoriented and political forms of solidarity action, which in the past used to be typical of many solidarity organisations, also beyond Germany (Baglioni 2001; Baglioni and Giugni 2014; Giugni 2001). 
Secondly, and partly interrelated with the observed politicisation, our study reveals that TSOs across all three fields underwent a clear transformation in the conceptualisation of (transnational) solidarity and the relationship towards their targets groups (also Fernández G. G. et al. 2020; Zschache et al. 2020). Many of the analysed TSOs are characterised by a new understanding of solidarity action that moves away from asymmetric top-down, help-oriented charity approaches towards more subject-centred, bottom-up and empowerment-oriented approaches. In this revised perspective, beneficiaries are regarded as equal, self-determined and selfresponsible persons with whom TSOs wish to interact at eye level. In the field of refugees, this conceptual change seems partly linked to the new actor structure that emerged in the context of the crisis and the role of new institutional entrepreneurs seeking to implement their own alternative views. To some extent, they are also a response to the new insight that many of the refugees will remain longer in Germany and thus have to be enabled to live a self-reliant life as equal society members, an idea which is reflected in the new "welcome culture" of 2015 and the growing acknowledgement that Germany is an immigration country. In the unemployment field, the new understanding is largely interrelated with the increased re-politicisation and mobilisation of many TSOs against the backdrop of significant deteriorations in unemployment policies and inadequate public and political support. In the disability field, the revised approach is directly connected with the ideas and principles promoted by the UN Convention on the Rights of Persons with Disabilities and the related objective to enforce equal human rights. Presumably, the change in thinking in this field has occurred rather incrementally and has already been prepared by changing ideas and demands since the 1970s. Thus, the transformed conceptualisation of transnational solidarity is embedded within different field-specific circumstances. At the same time, though, it resembles developments of solidarity organisations and movements on an international scale. Following the social movement literature, it seems to be a more general pattern of younger and more politicised transnational solidarity organisations and movements critically reflecting on and often rejecting the traditional guiding ideas of charity, neighbourly love, protection, care and assistance to the suffering, and to shift organisational orientation towards individual emancipation, societal democratisation, 
social and human rights, anti-racism and the idea of reciprocal, interdependent solidarity relations (della Porta and Massimiliano 2013; Eterovic and Smith 2001; Fernández G. G. et al. 2020; Giugni 2001: 236; Kousis and Paschou 2017; Passy 2001: 8-11; Waterman 2001: 236). Future research should, therefore, contribute to improving our understanding of how field-specific, country-specific and international context conditions and opportunity structures interrelate in shaping transnational solidarity organisations.

\section{References}

Aumüller, J. (2016). Flüchtlingszuwanderung und bürgerschaftliches Engagement. Betrifft: Bürgergesellschaft, 42. Berlin: Friedrich-Ebert-Stiftung.

Aumüller, J., Daphi, P., \& Biesenkamp, C. (2015). Die Aufnahme von Flüchtlingen in den Bundesländern und Kommunen. Behördliche Praxis und zivilgesellschaftliches Engagement. Stuttgart: Robert-Bosch-Stiftung.

Baglioni, S. (2001). Solidarity Movement Organizations: Toward an Active Global Consciousness? In M. Giugni \& F. Passy (Eds.), Political Altruism? (pp. 219-234). Lanham: Rowman \& Littlefield.

Baglioni, S., \& Giugni, M. (2014). Civil Society, Unemployment and Precarity in Europe: An Introduction. In S. Baglioni \& M. Giugni (Eds.), Civil Society Organizations, Unemployment, and Precarity in Europe. Between Service and Policy (pp. 1-10). London: Palgrave Macmillan.

Bandy, J., \& Smith, J. (2005). Factors Affecting Conflict and Cooperation in Transnational Movement Networks. In J. Bandy \& J. Smith (Eds.), Coalitions Across Borders (pp. 231-252). Lanham: Rowman \& Littlefield.

Baumgarten, B. (2010). Interessenvertretung aus dem Abseits. Campus: Frankfurt am Main.

BVerfG. (2019). Urteil des Ersten Senats vom 05. November 2019 - 1 BvL 7/16 -,

Rn. (pp. 1-225). Retrieved from: http://www.bverfg.de/e/ls20191105_ 1bvl000716.html

Collier, R. B., \& Collier, D. (1991). Shaping the Political Arena. Princeton: Princeton University Press.

Daphi, P. (2016). Zivilgesellschaftliches Engagement für Flüchtlinge und lokale ,Willkommenskultur'. Aus Politik und Zeitgeschichte, 66(14-15): 35-39. della Porta, D., \& Massimiliano, A. (2013). Protesting for Justice and Democracy: Italian Indignados? Contemporary Italian Politics, 5(1), 23-37. 
DiMaggio, P. J. (1988). Interest and Agency in Institutional Theory. In J. G. Zucker (Ed.), Institutional Patterns and Organizations (pp. 3-21). Cambridge: Ballinger.

Eterovic, I., \& Smith, J. (2001). From Altruism to a New Transnationalism? In M. Giugni \& F. Passy (Eds.), Political Altruism? (pp. 197-219). Lanham: Rowman \& Littlefield.

Fernández G. G., E., Kousis, M., \& Lahusen, C. (2020, forthcoming). Does Organization Matter? Solidarity Approaches of Transnational Organizations across eight European countries. In M. Kousis \& C. Lahusen (Eds.) Transnational Solidarity Organizations in Times of Crises: Comparative European Perspectives, Special Issue of Sociological Research Online.

Featherstone, D. (2012). Solidarity Hidden Histories and Geographies of Internationalism. London: Zed Books.

Fligstein, N. (1997). Social Skill and Institutional Theory. American Behavioral Scientist, 40(4), 397-405.

Fligstein, N. (2001). Institutional Entrepreneurs and Cultural Frames. European Societies, 3(3), 261-287.

Fligstein, N., \& Mara-Drita, I. (1996). How to Make a Market. The American Journal of Sociology, 102(1), 1-33.

Fligstein, N., \& McAdam, D. (2011). Toward a General Theory of Strategic Action Fields. Sociological Theory, 29(1), 1-26.

Giugni, M. (2001). Concluding Remarks. In M. Giugni \& F. Passy (Eds.), Political Altruism? (pp. 235-244). Lanham: Rowman \& Littlefield.

Glaser, B., \& Strauss, A. (1967). The Discovery of Grounded Theory. Chicago: Aldine.

Hamann, U., Karakayali, S., Wallis, M., \& Höfler, L. J. (2016). Koordinationsmodelle und Herausforderungen ehrenamtlicher Flüchtlingshilfe in den Kommunen. Berlin: Berliner Institut für empirische Integrations- und Migrationsforschung.

Hardy, C., \& Maguire, S. (2008). Institutional Entrepreneurship. In R. Greenwood, C. Oliver, R. Suddaby, \& K. Sahlin-Andersson (Eds.), The Sage Handbook of Organizational Institutionalism (pp. 198-217). London: Sage.

Karakayali, S. (2017). Feeling the Scope of Solidarity. Social Inclusion, 5(3), 7-16. Karakayali, S. (2018). Ehrenamtliches Engagement für Geflüchtete in Deutschland, State-of-Research Papier 09. Verbundprojekt ,Flucht: Forschung und Transfer', Osnabrück: Institut für Migrationsforschung und Interkulturelle Studien (IMIS) der Universität Osnabrück; Bonn: Internationales Konversionszentrum Bonn (BICC). 
Karakayali, S., \& Kleist, O. (2016). Strukturen und Motive der ehrenamtlichen Flüchtlingsarbeit (EFA) in Deutschland. Berlin: Berliner Institut für empirische Integrations- und Migrationsforschung.

Kingdon, J. W. (1995). Agendas, Alternatives, and Public Policy (2nd ed.). New York: HarperCollins College Publishers.

Köbsell, S. (2006). Towards Self-Determination and Equalization. Disability Studies Quarterly, 26(2). https://dsq-sds.org/article/view/692/869. Retrieved 10 May 2019.

Köbsell, S. (2019). 50 behindertenbewegte Jahre in Deutschland. Aus Politik und Zeitgeschichte, 69(6-7), 24-30.

Kousis, M., \& Paschou, M. (2016). Qualitative Interviews. In TransSOL (Ed.), Integrated Report on Reflective Forms of Transnational Solidarity (pp. 121-146). Retrieved from: http://blogs.uni-siegen.de/transsol/files/2016/12/IntegratedReport-on-Reflective-Forms-of-Transnational-Solidarity.pdf

Kousis, M., \& Paschou, M. (2017). Alternative Forms of Resilience. A typology of approaches for the study of Citizen Collective Responses in Hard Economic Times. Partecipazione e Conflitto, 10(1), 136-168.

Kousis, M., Lahusen, C., \& Loukakis, A. (2016). Transnational Solidarity Organisation Analysis. In TransSOL (Ed.), Work Package 2 Integrated Report on Reflective Forms of Transnational Solidarity (pp. 21-74). Retrieved from: http://blogs.uni-siegen.de/transsol/files/2016/12/Integrated-Report-onReflective-Forms-of-Transnational-Solidarity.pdf

Kousis, M., Giugni, M., \& Lahusen, C. (2018). Action Organization Analysis: Extending Protest Event Analysis Using Hubs-Retrieved Websites. American Behavioral Scientist, 62(6), 739-757.

Kühne, P., \& Rüßler, H. (2000). Die Lebensverhältnisse der Flüchtlinge in Deutschland. Frankfurt am Main: Campus.

Lahusen, C., \& Baumgarten, B. (2010). Das Ende des sozialen Friedens. Frankfurt am Main: Campus.

Leca, B., Battilana, J., \& Boxenbaum, E. (2009). How Actors Change Institutions: Toward a Theory of Institutional Entrepreneurship. Academy of Management Annals, 3(1), 65-107.

Linnert, J. (2018). Freiwilliges Engagement mit Geflüchteten als Beitrag zur Integration in Kommunen. Working Paper III des Projekts Perspektive Teilhabe, Berlin: Minor.

Maskos, R., \& Siebert, B. (2006). Self-Determination: The Other Side of the Coin. Disability Studies Quarterly, 26(2). https://dsq-sds.org/article/view/ 693/870. Retrieved 10 May 2019. 
Matzat, J. (2010). Ehrenamtliches Engagement, kollektive Selbsthilfe und politische Beteiligung im Gesundheitswesen. In T. Olk, A. Klein, \& B. Hartnuß (Eds.), Engagementpolitik (pp. 547-570). Wiesbaden: VS Verlag.

Mayring, P. (2004). Qualitative Content Analysis. In U. Flick, E. von Kardorff, \& I. Steinke (Eds.), A Companion to Qualitative Research (pp. 266-269). London: Sage.

McAdam, D., McCarthy, J. D., \& Zald, M. N. (1996). Comparative Perspectives on Social Movements. Cambridge, UK: Cambridge University Press.

Misbach, E. (2015). Sich für Gesundheit starkmachen' - Solidarische Flüchtlingsarbeit als gemeinsamer sozialer Kampf um Rechte. zeitschrift für menschenrechte, 2, 122-135.

Passy, F. (2001). Political Altruism and the Solidarity Movement: An Introduction. In M. Giugni \& F. Passy (Eds.), Political Altruism? (pp. 3-25). Lanham: Rowman \& Littlefield.

Rada, A., \& Stahlmann, A. (2017). Freie Wohlfahrtspflege und Sozialstaat. Frankfurt a.M.: Institut für Sozialarbeit und Sozialpädagogik.

Rao, H., Morrill, C., \& Zald, M. N. (2000). Power Plays: How Social Movements and Collective Action Create New Organizational Forms. Research in Organizational Behaviour, 22, 239-282.

Rehklau, C. (2017). Flüchtlinge als Adressat_innen sozialer Arbeit? In C. Ghaderi \& T. Eppenstein (Eds.), Flüchtlinge-multiperspektivische Zugänge (pp. 305-322). Wiesbaden: Springer VS.

Rein, H. (2013). Geschichte des organisierten Erwerbslosenprotestes in Deutschland (1945-2010). In H. Rein (Ed.), DreißigJahre Erwerbslosenprotest 1982-2012 (pp. 43-66). Neu-Ulm: AG-SPAK.

Rohrmann, E. (1999). Vom ,brüllenden Löwen` zum ,kläffenden Schoßhund'. In P. Günther \& R. E. Peter (Eds.), Soziale Selbsthilfe (pp. 52-86). Heidelberg: Universitätsverlag C. Winter.

Schiffauer, W. (2017). Einleitung. Eine neue Bürgerbewegung. In W. Schiffauer, A. Eilert, \& M. Rudloff (Eds.), So schaffen wir das (pp. 13-34). Bielefeld: transcipt.

Schmid, S. (2019). Taking Care of the Other. Social Inclusion, 7(2), 118-127.

Schneiberg, M., \& Lounsbury, M. (2008). Social Movements and Institutional Analysis. In R. Greenwood, C. Oliver, R. Suddaby, \& K. Sahlin-Andersson (Eds.), The Sage Handbook of Organizational Institutionalism (pp. 648-670). London: Sage.

Schroeder, W., \& Kiepe, L. (2019). Konfliktpartnerschaft zwischen konfessionellen Wohlfahrtsverbänden und Staat in der Krise des Migrationsstaates 2015/2016. In O. Hidalgo \& G. Pickel (Eds.), Flucht und Migration in Europa (pp. 161-188). Wiesbaden: Springer VS. 
Smith, J. (2002). Bridging Global Divides? International Sociology, 17(4), $505-528$.

Snow, D. A., Rochford, E. B., Jr., Worden, S. K., \& Benford, R. D. (1986). Frame Alignment Processes, Micromobilization, and Movement Participation. American Sociological Review, 51(4), 464-481.

Speth, R., \& Becker, E. (2016). Zivilgesellschaftliche Akteure und die Betreuung geflüchteter Menschen in deutschen Kommunen. Berlin: Maecenata Institut, Opusculum 92.

Steinhilper, L., \& Fleischmann, E. (2016). The Myth of Apolitical Volunteering for Refugees. Social Inclusion, 5(3), 17-27.

Sutter, O. (2017). Willkommen!' Emotionale Politiken des zivilgesellschaftlichen Engagements für Flüchtende. Zeitschrift für Volkskunde, 113(1), 3-23.

Tesch-Römer, C., Simonson, J., Vogel, C., \& Ziegelmann, J. P. (2017). Ergebnisse des Deutschen Freiwilligensurveys 2014. In J. Simonson, C. Vogel, \& C. Tesch-Römer (Eds.), Freiwilliges Engagement in Deutschland (pp. 647-662). Wiesbaden: Springer VS.

TransSOL (2016). Work Package 2 Integrated Report on Reflective Forms of Transnational Solidarity. Retrieved from: https://blogs.uni-siegen.de/transsol/files/2016/12/Integrated-Report-on-Reflective-Forms-of-TransnationalSolidarity.pdf

Twickel, C. (2016). Refugees Welcome: Vom Slogan zum Sommermärchen. Retrieved from: https://heimatkunde.boell.de/2016/03/03/refugees-welcomevom-slogan-zum-sommermaerchen

Voigtländer, L. E. (2015). Armut und Engagement. Bielefeld: Transcript.

Waterman, P. (2001). Globalization, Social Movements and the New Internationalism. London: Continuum.

Zamponi, L. (2017). Practices of Solidarity: Direct Social Action, Politicisation and Refugee Solidarity Activism in Italy. Mondo Migranti, 3, 97-117.

Zamponi, L., \& Bosi, L. (2018). Politicizing Solidarity in Times of Crisis: The Politics of Alternative Action Organizations in Greece, Italy, and Spain. American Behavioral Scientist, 62(6), 796-815.

Zschache, U., Theiss, M., \& Paschou, M. (2020, forthcoming). What Is Solidarity About? Views of Transnational Solidarity Activists in Germany, Poland and Greece. In M. Kousis \& C. Lahusen (Eds.) Transnational Solidarity Organizations in Times of Crises: Comparative European Perspectives, Special Issue of Sociological Research Online. 
Open Access This chapter is licensed under the terms of the Creative Commons Attribution 4.0 International License (http://creativecommons.org/licenses/ by/4.0/), which permits use, sharing, adaptation, distribution and reproduction in any medium or format, as long as you give appropriate credit to the original author(s) and the source, provide a link to the Creative Commons licence and indicate if changes were made.

The images or other third party material in this chapter are included in the chapter's Creative Commons licence, unless indicated otherwise in a credit line to the material. If material is not included in the chapter's Creative Commons licence and your intended use is not permitted by statutory regulation or exceeds the permitted use, you will need to obtain permission directly from the copyright holder.

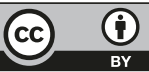

